\title{
THE HERITIZATION OF BULGARIAN ROSE
}

Vesselin Loulanski, Tolina Loulanski

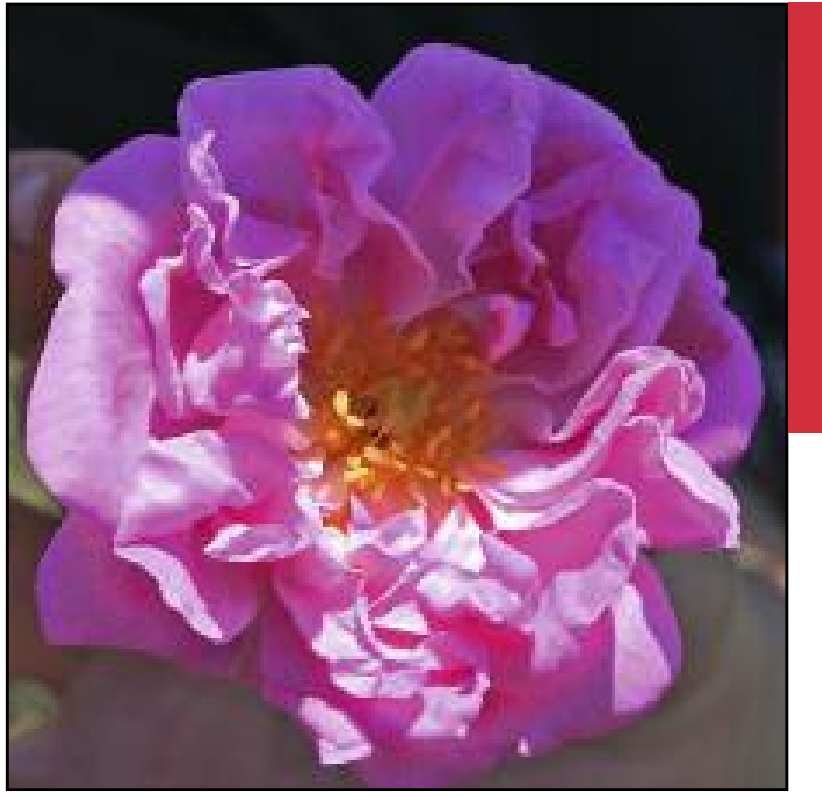

The Bulgarian Damascena Rose. 


\section{The heritization of Bulgarian rose}

DOI: http://dx.doi.org/10.3986/AGS54408

UDC: 338.48-6:633.811(497.2)

633.811(497.2)

COBISS: 1.01

ABSTRACT: Bulgarian rose products are well known for their premier fragrance quality and are often used as a base ingredient in a number of high-end perfumery and cosmetics products. While a result of unique combination of relief, climate and soil conditions, the cultivation and production process largely depends on manual labor, and entails a rich variety of techniques, rituals and social practices. The latter have been turned into tourism attractions gaining popularity in the cultural events calendar. Grounded within the wider discourse of the qualitative method, the present study examines the origin, history and development of the rose cultivation culture and its associated practices that have led to the heritization of the Bulgarian rose. It advocates that a natural synergy between heritage and tourism development has occurred, serving sustainable tourism purposes, with tourism adding to the protection and enhancement of rose heritage values, and supporting regional economies.

KEY WORDS: Bulgarian rose, heritization, cultural tourism, sustainability

The article was submitted for publication on December 20, 2012

ADDRESSES:

Vesselin Loulanski, Ph. D.

European College of Economics and Management

18 Zadruga Street, 4004 Plovdiv, Bulgaria.

E-mail: loulanski@ecem.org

Tolina Loulanski, Ph. D.

Foundation »Plovdiv 2019«, Old Plovdiv Architectural Reserve, 6 Arch. Hristo Peev Street, 4000 Plovdiv, Bulgaria E-mail: tolinaloulanski@yahoo.co.jp 


\section{Introduction}

Bulgaria is widely known as the country of roses due to the high popularity and appeal of the rose flower, as well as to the expanding heritage values related to its traditional growing and the production of premium rose products. Pictures of the Rose Valley and the Rose Festival are frequent eye-catchers in the web pages and brochures of Bulgarian and foreign tourism agencies, cosmetics and food companies. In fact, the Bulgarian rose has a fairly long history as a national symbol reaching back to the time of the World Fairs in Chicago 1893, Liege 1905, Milan in 1906 and 1907, and the Bulgarian rose oil has received gold medals at exhibitions in Paris, London, Philadelphia, Antwerp, and Milan.

The Bulgarian rose belongs to the Rosa Damascena Mill $\mathrm{f}$. Trigintipetala Dieck group and has formed as a result of a natural human selection during the last 340 years (Kovatcheva 2011). The Bulgarian rose is grown in the area named the Rose Valley that is about $130 \mathrm{~km}$ long, 1 to $16 \mathrm{~km}$ wide, with altitudes ranging from 375 to $711 \mathrm{~m}$. The climate is mild, temperate continental, featuring warmer winters, cooler summers, higher rain falls and humidity. The southern slopes of the Balkan Mountains $(2376 \mathrm{~m})$ and the northern slopes of Sredna Gora Mountains $(1604 \mathrm{~m})$ that shape the Valley serve as natural protection from strong winds, while its diluvial sedimented soils add to the favorable conditions for growing the rose plant. The Bulgarian rose is a perennial bush with a body of 1,5-2 meters of height, and roots reaching $1-5 \mathrm{~m}$ of length. The rose flowers are big, pink, with strong pleasant aroma that blossom in a row at the end of May and in the beginning of June, during a period of only 12 days in dry hot weather to 25-30 days in humid and cool weather. The essential oil accumulates on the surface of the rose petals and evaporates quickly, that is why the low humidity of the air and dry winds during the blossom period negatively affect the quality of the extracted oil. The oil comprises as many as 300 different constituents, which make the overall scent stronger than that of any other rose (Nedkov et al. 2005). Because of its rich and sustainable aroma, the Bulgarian rose oil has become a benchmark for quality accounting for approximately half of the world market of essential rose oil.

The historical evidence reveals a strong presence of the rose culture in Bulgaria since the time of the Thracian Odryssian Kingdom $\left(5^{\text {th }}-3^{\text {rd }}\right.$ century BC). In its Natural History book, Pliny the Elder points to the attar of roses (rose oil) as one of the most widely used perfume ingredients of the time (Pliny the Elder 2013). It is no surprise that the area of the Valley of Roses closely matches that of the Valley of the Thracian kings known for the thousands of burial mounds spread throughout the territory. In the past, after Thrace has become a province in the Roman Empire, and later during the First (681-1018) and Second (1185-1396) Bulgarian Kingdoms until the time of the modern Bulgarian state, the rose was recognized for possessing rich symbolic power and was widely used in Thracian rituals and ceremonies, in paintings of daily life, battles, burial and other ritual scenes, as ornaments on horse trappings, cosmetic boxes and alabastrons (small pottery containers holding perfume or massage oils), sculptural objects, precious metal works, jewelry, armors, roman mosaics, Christian iconography, books, traditional Bulgarian Revival period architecture, furniture, interior objects, rose-patterned carpets and rugs, porcelain, local cosmetics and foods such as jam, liquor, pastry and others. The rich historic record of the presence and the invariable appreciation of the rose flower in Bulgaria represent the source and background for the currently observed heritization of the Bulgarian rose, a process that will be discussed further in the text.

\section{Rose production, trade and regulations}

The Bulgarian rose needs a 3-year period after plantation to collect the first blossoms. If properly treated, the rose field can be used for production for a period of 25-30 years. The growing is a difficult process consisting of no less than 10 different operations, however it is the rose picking being the most labor intensive, accounting for nearly half of the overall production expenses. For centuries the rose picking has been performed by hand in the hours between 5-10 am, with best rose oil composition around $7 \mathrm{am}$. The blossoms are gathered into closed plastic bags and quickly transported to the nearby distillery. The common yield is 5 tons of blossoms from 1 hectare, while well-maintained plots can give up to 10-12 tons (Atanasova and Nedkov 2004). The distillation of the flower is performed using water or water-steam distillation that extracts the rose oil from the rose water. It is interesting to note that the region's long tradition of wine making and especially of brandy distillation has contributed for several important technological innovations that 
allowed higher yields and better quality. These are the introduction of double distillation, the interminable cooling system, and the use of special combustibles for steady moderate heating. The processing delivers several different products: rose oil, rose absolute, rose concrete, rose water and other secondary products. Under normal storage conditions the rose oil could keep its qualities for decades. The production of 1 liter of rose oil requires about 3-3,5 $\mathrm{t}$ of rose blossoms. The local rose oil production topped $1,5 \mathrm{t}$ in 2012 .

In the beginning of the 20th century the rose fields spread over some 9000 ha, decreased to 700 ha during the 1997 crisis, however recovered to 3600 ha in 2012. Almost half of the plots are owned by cosmetics companies, while the other half belongs to small private owners. There are some 30 to 50 rose distilleries, with 12-13000 people employed on a full time basis in the rose industry (Zarev 2008). Most of the rose produce is exported to France, USA, Japan, UK, Germany, and just 1-5\% is used by the local cosmetics and food industry, some of which for the production of traditional souvenirs. The international market of essential oils is sometimes compared to those of diamonds, being the monopoly of several global trading companies, mainly from France and the USA that buy up oils from all over the world. That fact makes it difficult for a Bulgarian producer to directly sell to foreign cosmetics companies, which in turn drastically reduces the positive impacts for the community, failing to gain from the potential of heritage to play a much more significant role in local development; instead this niche product almost always ends traded as a raw material.

At present, the Governmental Institute of Roses, Essential and Medical Cultures remains one of the main centers for research and development engaging in the creation and maintenance of a gene fund of 216 sorts and 161 essential oil and medical plants varieties (Institute of roses ... 2013). Previously, a number of legislative acts have been introduced to regulate and support the rose production and trade. Among them are the Support Act of Rose Production (1922) and the Decree-Law to Regulate the Manufacture and Sale of Rose Oil (1937). Recently there have been two initiatives by the Committee of Agriculture and Forestry to pass the newly proposed Rose Production Act (Rose Production Act 2003, 2004) through the National Assembly, however still in a discussion phase. In the arguments for proposing the act it is clearly stipulated

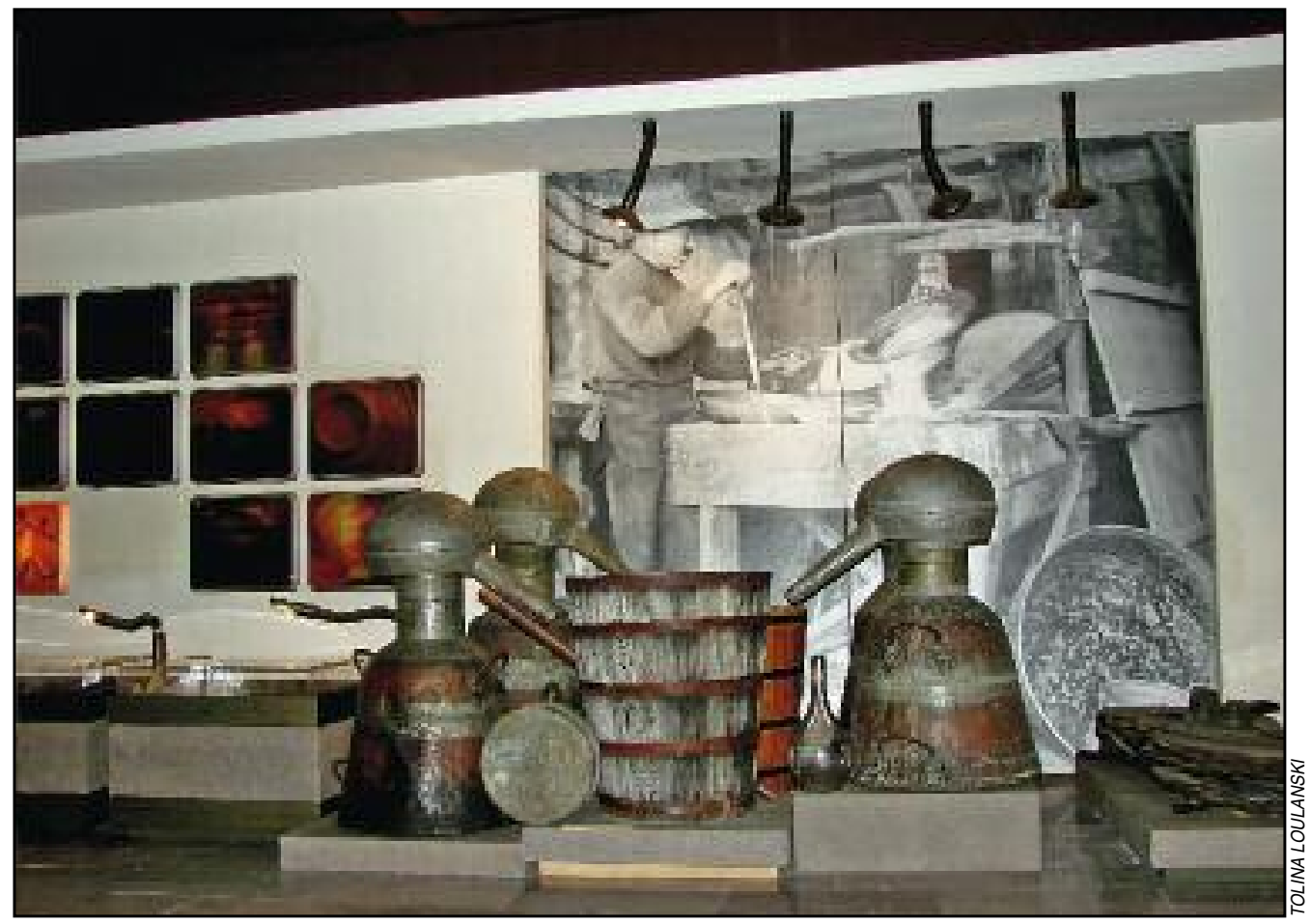

Figure 1: The historical museum Karlovo, Bulgaria. 
that the Bulgarian rose and rose oil have grown into important symbols of national identity and pride, not only due to their unique geographical origin traced to the Rose Valley, but also due to the equally distinctive social and cultural capital of the people involved in the process revealing itself in the development of skills, techniques, traditions, rituals, and diligence in growing roses and producing various rose-derived products.

\section{The rose heritage for perfumery and medicinal purposes}

There are now approximately 2805 fragrances that incorporate the rose scent. This number stands at almost one third of all fragrances listed on http://www.basenotes.net, one of the largest fragrance-related portals on the internet. Here are some of the most known perfumes that indicate the use of Bulgarian rose oil: Acqua di Parma Colonia (1916) by Acqua di Parma; Coco (1984), Bois des Îles (1926), Coco Mademoiselle (2012), Égoïste (1990), No. 19 (1971), No. 5 (1921) by Chanel; Eau Sauvage (1966), Dioressence (1969), Dolce Vita (1995), Dior Addict (2004), Midnight Poison (2007), Miss Dior (2012) by Christian Dior; Fleurs de Bulgarie [created for Queen Victoria in the 19th Century] (1980), Love In White (2005), Amalfi Flowers (2007), Acqua Fiorentina (2009), Windsor (2009) by Creed; Champs-Elysées (1904), Mitsouko (1919), Habit Rouge (1965), Eau de Guerlain (1974), Idylle (2009), La Petite Robe Noire (2012) by Guerlain; Flower (2000) by Kenzo; Rose (2009) by Paul Smith; Infusion de Rose (2011) by Prada; Rose Absolute (2005) by Stella McCartney; Tom Ford Noir (2012) and Café Rose (2012) by Tom Ford; Bulgarian Rose (2012) by Zara.

The allocation of perfumes with rose notes exhibits a sharp and relatively constant increase in numbers for the last several decades: 86 perfumes with rose notes registered until 1960; 20 for the period between 1960-1970; 80 for 1970-1980; 153 for 1980-1990; 265 for 1990-2000; 1149 for 2000-2012; and a total of 908 between 2010 and 2012, showing a compound annual rate of growth for the period 1970-2012 close to $10 \%$ ! Altogether, the evident 'blooming rose' trend and the parallel association of the Bulgarian rose with high-end designer brands and products contributes greatly for augmenting the rose value by generating two-way effects both to the place of origin (boosting tourism, revenues and investments, enhancing local reputation, diversifying uses and products, increasing market share) and to the products themselves (promoted as natural, heritigized, and of certified origin).

Similar to the trend in perfumery, the rose is gaining other functions and uses transforming into a wide range of medicinal products (as eye drops, stomach function regulator, gallstone cleaner, rejuvenating and anti-inflammatory skincare, respiratory regulator, anti-sclerosis treatment, immune stimulant, anti-HIV treatment) and wellness products (in aroma-therapy, anti-age cosmetics) (Komaki, 2006). Many Japanese companies have developed special thematic lines of Bulgarian rose products, among which are » Yamamoto Perfumery « with the production of lipsticks, tea, cookies, jelly, body odor pills and others and »Shiseido" with its renowned »Rosarium« cosmetic line.

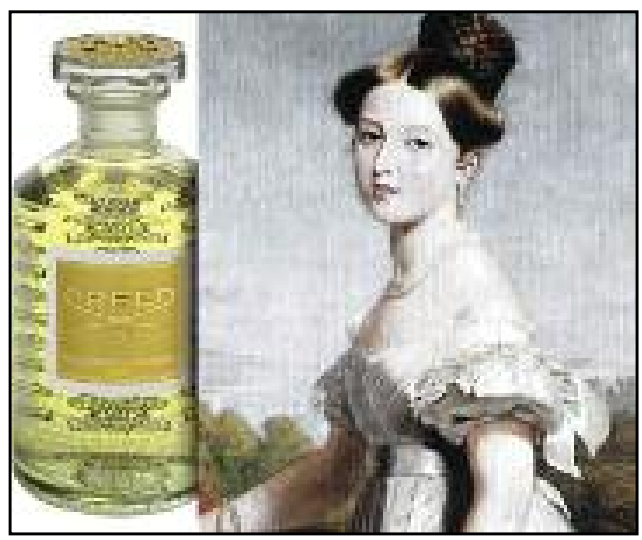

Figure 2: Fleurs de Bulgarie, one of the oldest CREED fragrances, commissioned by Queen Victoria in 1845 (Source: www.fragrantica.com). 


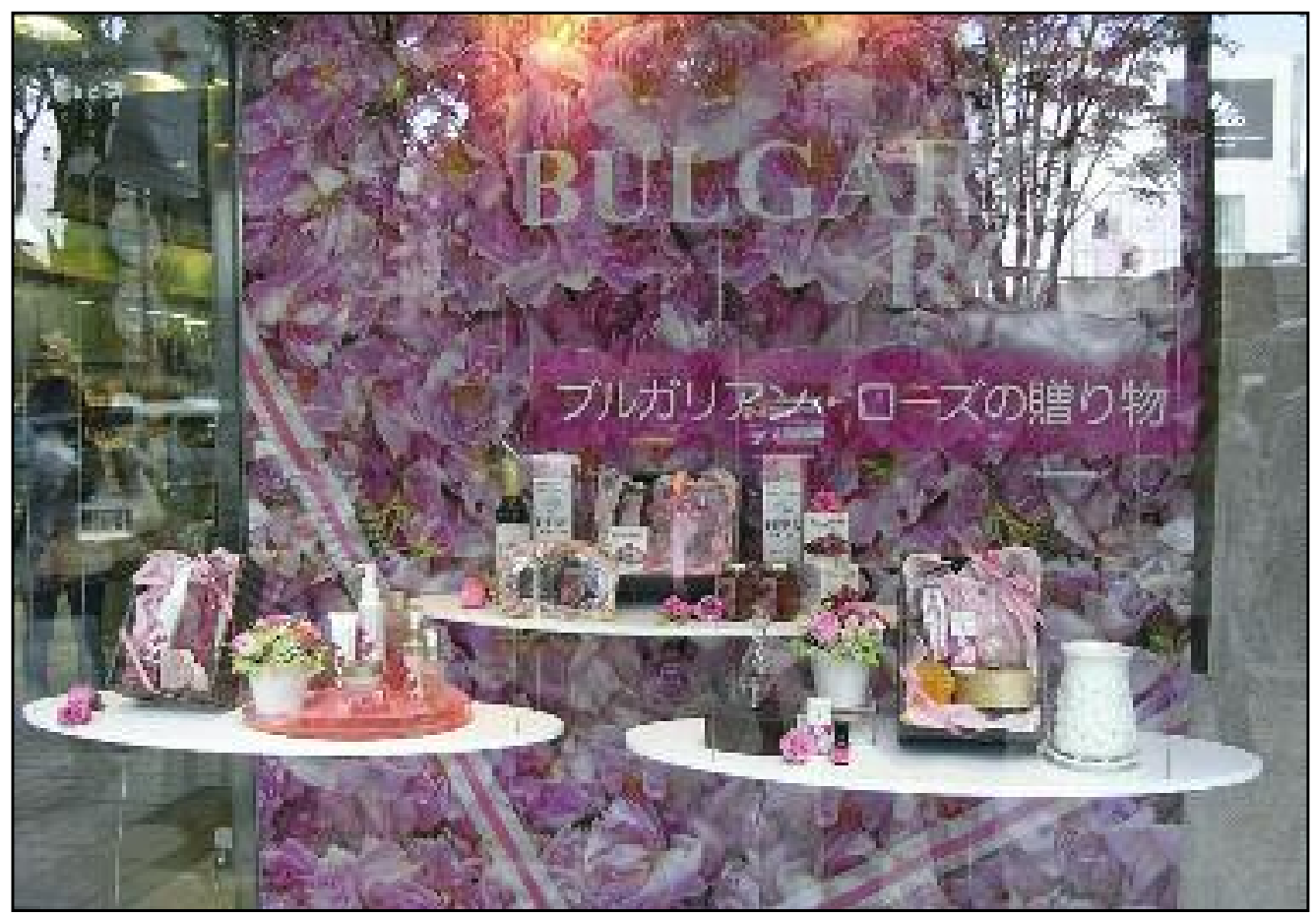

Figure 3: Bulgarian rose products display, Omotesando, Tokyo (Source: Tree of life Co., Ltd).

Figure 4: Bulgarian rose extract capsules

(Source: Pillbox, Japan)

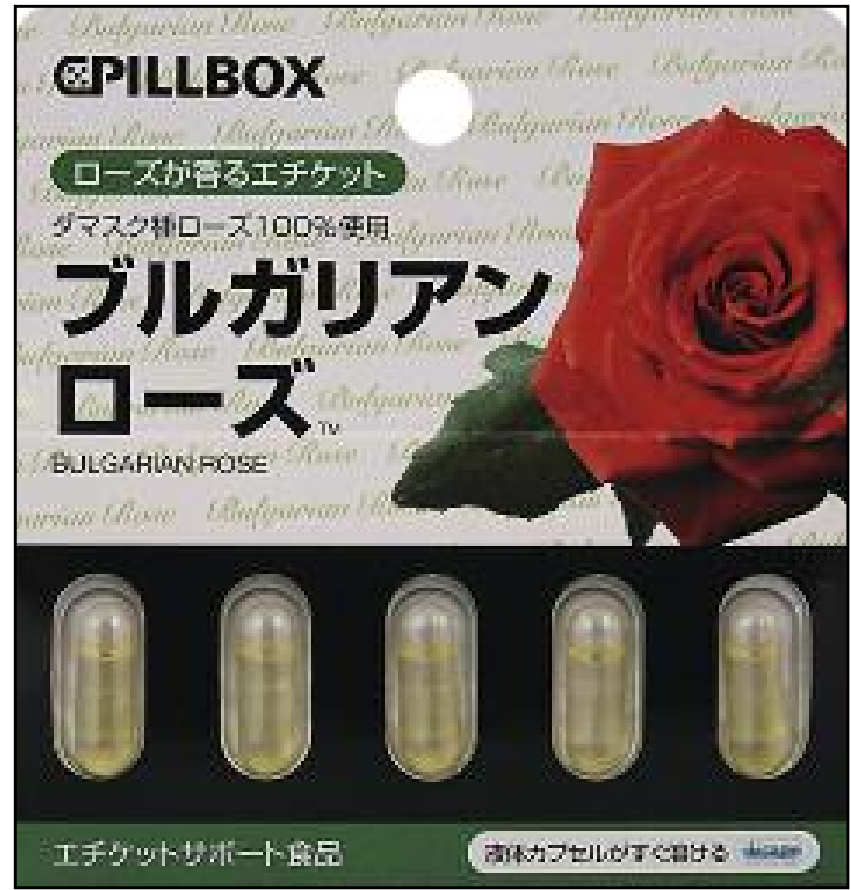




\title{
4 Towards sustainable integration of rose heritage, tourism and regional development
}

\begin{abstract}
Before going further into the subject of heritization, one need to give credit to the research field that studies the phenomenon. Heritage studies has gained recognition as the new core multi-disciplinary field, exploring the impact of heritage on the present and endeavouring the development of new holistic approaches to address more adequately the challenges related to cultural heritage. The field is characterized by complexity and wide scope of subjects as scholars show particular interest in the social dimension of heritage, its contemporary roles and multiple uses as a cultural, economic, social and political resource (Graham et al, 2000; Tunbridge and Ashworth, 1996). By definition, cultural heritage includes both material or built aspects of culture (sites, buildings, landscapes, museums, monuments, and objects), as well as the non-material or living heritage that is embodied in social practices, community life, values, beliefs, and expressive forms (language, arts and handicrafts, music, dance, etc.). The concept of heritage has been changing as a result and according to the changing attitudes, needs and demands people convey towards it, shifting alongside several interrelated complementary directions: 1) from monuments to people; 2) from objects to functions; and thus 3 ) from preservation per se to purposeful preservation, sustainable use, and development (Loulanski 2006). This recently recognized human aspect of heritage has given birth to a movement towards ascribing multiple values, wider definitions and roles of cultural heritage in society, a process known as heritization.
\end{abstract}

Certainly, some of the most common and frequently discussed uses of heritage are for tourism purposes. In general, the development of tourism in the Rose valley region brings direct, secondary and induced effects. The direct effects include the impact of the rose culture on the incentives to visit the valley, stay at a local hotel, go to the local restaurants, visit the local tourist facilities and cultural attractions, buy local products, and can be measured by calculating the direct monetary revenues. The secondary effects include the growth of industries and investments in tourism services, construction and infrastructure, finance, energy, the food sector, and in the overall economic regional development. The third group comprises the so-called induced effects, which refer to the benefits gained by the local population in terms of employment, salaries, income from rents, etc. It is important to note that there are significant image and brand improvement spill-over effects that not only benefit the region but the whole country. The latter are difficult to measure, yet it is only when the combined monetary income for these three groups of effects are properly accounted for that the full economic impact of the rose-based tourism in the valley as part of the national tourism sector could be estimated.

The focal visitor attraction in the Rose valley is the world-famous Rose festival, officially introduced as part of the cultural calendar of the region in 1903, launched initially as a charity and later as a peace and friendship event. It is usually held for over a month in the second half of May and the first half of June. Each of the participating cities has its own agenda (Kazanlak and Karlovo since 1903, Pavel Banya since 1966, Strelcha since 1996), organized by the cultural departments of the municipalities or the local community centers. The programs vary year by year and are usually communicated on the internet sites of the municipal and tourism information centers. Usually, the festival features activities such as rose picking, rose distillation, tasting rose products, taking part in music, folklore and art activities, a rose queen beauty contest, local crafts demonstrations, tasting wine and regional cuisine, taking part in scenery tours, plain air painting, sports games, and a kukeri parade (an old Thracian ritual to scare away evil spirits and bring health, happiness and good harvest, with masked men in peculiar costumes walking, dancing and ringing large bells attached to their waists). Sometimes, scenes of traditional Bulgarian wedding are performed, and tourists have the chance to join the circle dance of horo under live folklore music of bagpipes, drums and traditional flutes. The peak in visitor numbers for the festival is said to have been in 1975 when Karlovo town stadium welcomed 30000 guests, 3500 of whom foreigners. Generally, most numerous are the organized groups of Bulgarian, European, Japanese and American tourists. Nevertheless, the socio-economic impact of the festival could hardly be measured alone by the number of hotel reservations, the turnover in services and retailing. The significance of the festival has more to do with non-monetary returns such as preserving and appreciating the tradition, showing hospitality, celebrating and sharing the uniqueness and spirit of place. 2013 will mark the $110^{\text {th }}$ anniversary of the Rose festival providing opportunity to once again reevaluate its significance for the region. 
In addition to the festival, the heritage of the Bulgarian rose needs to be further explored in terms of its belonging to the cultural landscape category in its capacity to combine nature, history, culture, and the living heritage. By definition, this type of heritage refers to the formal expression of numerous relationships existing in a given period of time between a society and a topographically defined territory, the appearance of which is the result of the action over time of natural and human factors and of a combination of both (Jokilehto 2004). The protection of cultural landscapes in many regions of the world contribute to modern ways of sustainable land-use that maintain or enhance the natural values in the landscape and the continued existence of traditional land-use patterns that support biological diversity (UNESCO 2005).

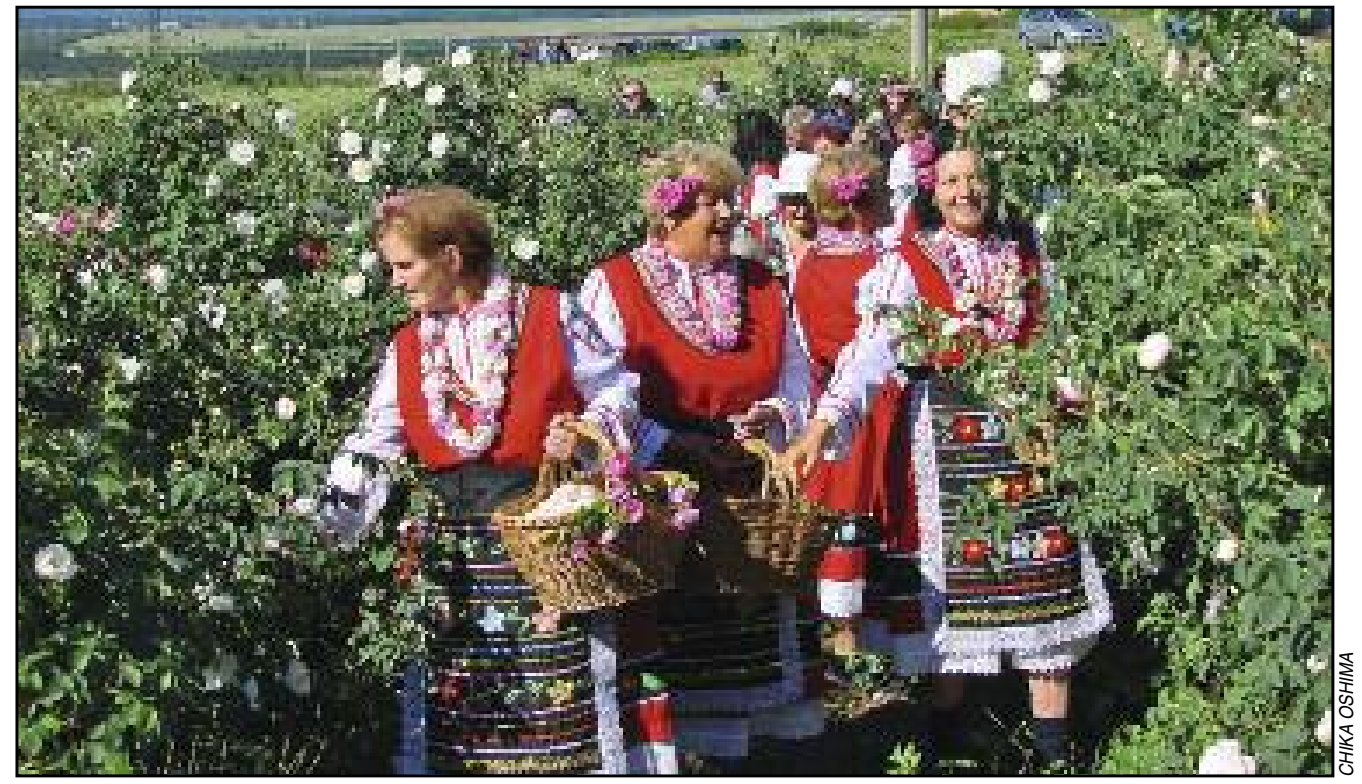

Figure 5: Scene from the Rose Festival, 2011.

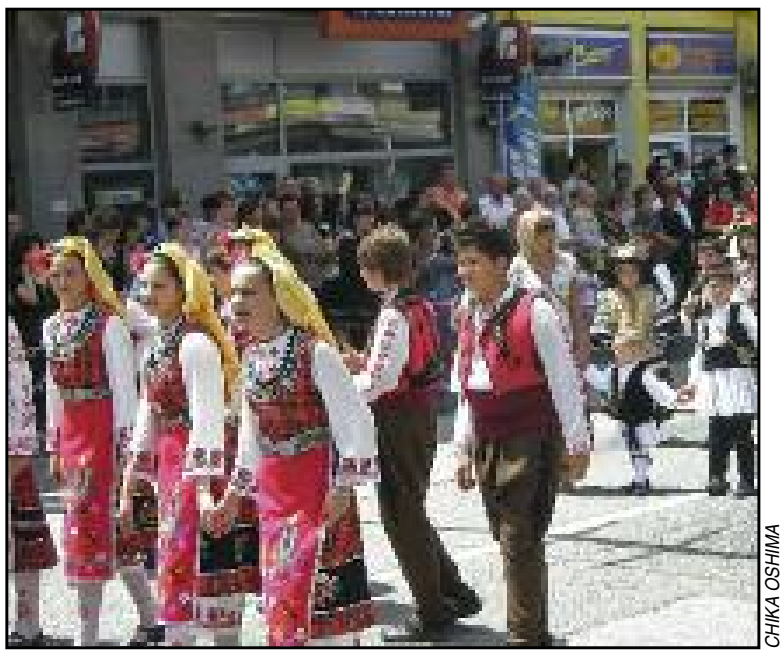


Finally, two important points relevant to the sustainable integration of the rose heritage and the growing tourism industry in the region should be made. First, heritage should be identified in its capacity not just as a tourism resource, but as an important and largely irreplaceable complex form of capital (cultural, social, environmental and economic), which should be wisely used, sustained and enhanced, instead of being irretrievably consumed by tourism. Raising the economic value of heritage by way of tourism can surely increase its cultural value, however, it cannot compensate for the loss of other values in the long-term. Preventive management, planning and regulation are considered essential prerequisites to this end. Second, the incorporation of both heritage and tourism policies within the wider regional sustainable development strategies should be seen as a critical factor for ensuring integrated governance and long-term strategic planning necessary to guarantee sustainability of the heritage and tourism relationship. To remember, sustainable tourism is that kind of tourism that is "non-intrusive" and "non-degrading " of heritage sites, sensitive to both the environment and the communities, respecting local values, aiming at preserving and enhancing the very environmental and cultural amenities which have attracted tourists in the first place (Loulanski and Loulanski 2011). Instead of seeking short-term profits from the exploitation of tourism resources, regional sustainable tourism strategies should be aimed at achieving long term win-win outcomes, with positive effects on both cultural values and economic profitability (Throsby 2001). For this reason, the process has to be multi-dimensional, requiring active participation and closer cooperation of local communities in cultural heritage management and tourism planning, balance of interests and partnership among the different stakeholders at the destination: local residents, government and regional authorities, tourism industry representatives, and tourists themselves.

\section{Conclusion}

In a time when identity becomes increasingly important in counterbalancing the effects of globalization, breaking down spatial and temporal barriers, cultural heritage grows to a new dimension, becoming a key factor in ensuring local distinctiveness (Strange 1999). This article discussed the socially-rooted process of heritization of the Bulgarian rose, indicating an expanding spectrum of modern purposes and uses, as well as a growing awareness to refer and build upon its newly recognized multiple values. In addition to the historically strong record of various cultural uses of the rose heritage in symbols, rituals, traditional folklore, arts, crafts, events and festivals, at present, the growing synergy with tourism stands out as an approach that could enhance its fundamental values even further as an important catalyst of a sustainability-aimed socio-economic development.

\section{References}

Atanasova, M., Nedkov, N. 2004: Essential oil and medicinal plants: contemporary technologies for growing, competitiveness, financing [in Bulgarian]. Sofia.

Rose Production Act (proposal) [in Bulgarian]. National Assembly of the Republic of Bulgaria No. 354-01-36/ 29.05.2003; 454-01-99/12.10.2004. Sofia.

Graham, B., Ashworth, G., Tunbridge, J. 2000: A Geography of heritage - power, culture and economy. London.

Institute of roses, essential and medical cultures. 2013. Internet: http://www.iremk.net/en/index.php (5.3.2013).

Jokilehto, J. 2004: Sustainability and the integrated urban heritage management. The sustainable urban heritage management - local community in time of change - expert seminar, 21-24 April, 2004). Vilnius.

Komaki, R. 2006: New components of rose oil and its properties. Koryo 229.

Kovatcheva, N. 2011: Selection of oil-bearing rose in Bulgaria - tendencies and perspectives. Agricultural science and technology 3-3. Trakia University. Stara Zagora.

Loulanski, T. 2006: Revising the concept for cultural heritage: the argument for a functional approach. International journal of cultural property 13-2. DOI: http://dx.doi.org/10.1017/S0940739106060085

Loulanski, T., Loulanski, V. 2011: The sustainable integration of cultural heritage and tourism: a meta-study. Journal of sustainable tourism 19-7. DOI: http://dx.doi.org/10.1080/09669582.2011.553286

Nedkov, N., et al. 2005: Handbook on the basic essential oil and medicinal plants [in Bulgarian]. Kazanlak. 
Pliny the Elder. The Natural history 21, The rose: twelve varieties of it. Internet: http://www.masseiana.org/ pliny.htm (5.3.2013).

Strange, I. 1999: Urban sustainability, globalization and the pursuit of the heritage aesthetic. Planning practice and research 14-3. DOI: http://dx.doi.org/10.1080/02697459915616

Throsby, D. 2001: Economics and culture. Cambridge.

Tunbridge, J., Ashworth, G. 1996: Dissonant heritage: the management of the past as a resource in conflict. Chichester.

UNESCO. 2005: World Heritage Operational Guidelines.

Zarev, K. 2008: Bulgarian rose production and the traditional culture. Kazanlak. 